\title{
前縦隔巨大腫瘍に対する全身麻酔下の生検 および根治手術の問題点
}

近藤和也*

\section{はじめに}

本号に掲載された植田一吉らの症例報告 “全身麻 酔下で生検手術中にガス交換不全に陥つた前縦隔腫 瘍の 1 例” は大変示唆に富む論文であり, 前縦隔巨 大腫瘍の治療に当たる内科, 外科, 麻酔科医が全身 麻酔導入時の病態を十分把握していないと致死的な 結果に陥ってしまう危険性を指摘している，私も研 修医時代に一例経験した。

前縦隔腫瘍は比較的まれな疾患であり, 胸腺腫, 胸腺癌, 奇形腫や悪性リンパ腫などがある ${ }^{12,2)}$. 解 剖学的な位置により胸部 X 線写真では早期に発見す ることは困難であり, 発見時, 腫瘍径が大きいもの がほとんどである。特に, 悪性胚細胞性腫瘍や悪性 リンパ腫は短期間で急速に増大する．前縦隔巨大腫 瘍に対して, 切除および生検目的で全身麻酔を施行 するとき, 致死的な呼吸不全や循環不全に陥る場合 がある. 原因として 1) 心臓の圧迫，2）大血管, 特 に上大静脈 (SVC) や肺動脈の圧迫，3) 気管・主気管 支の圧迫，が考えられる ${ }^{3)}$. 前縦隔巨大腫瘍の麻酔 時, 致死的な呼吸不全や循環不全を防止するため, 術前の診断・治療および麻酔導入時の十分な準備に ついて, 文献的考察を加え, 詳述する.

\section{1. 前縦隔巨大腫瘍の確定診断に対しては, 全身麻酔下} の生検は避け，局所麻酔下の針生検を行うべきである 前縦隔は, 胸腺腫, 奇形腫, 悪性リンパ腫の好発 部位である。前縦隔腫瘍は病歴の聴取と症状から病 名を予測することが可能である，悪性胚細胞性腫瘍 は圧倒的に男性に多く, 思春期および 20 歳前後の年 秢層にかぎられている．縦隔の悪性リンパ腫の多く は35歳以下に多い. 胸腺腫は特異な合併症を伴うこ とが多く, 重症筋無力症 (合併率 16〜24\%), 赤芽 球疼 (合併率 $1.5 \sim 2.4 \%$ )，低または高 $\gamma$ ーグロブリ ン血症などを合併する．重症筋無力症では眼瞼下垂， 複視, 四肢脱力, 発語, 嬿下障害を訴えたり, 赤芽 球瘞では貧(血を呈する ${ }^{12,2), 4) . ~}$

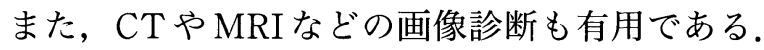
胸部 CT 検査の所見としては, 悪性リンパ腫は CT にて内部構造は均一で, 胸腺腫は内部構造はほぼ均 一であるが，石灰化や小さな囊胞形成を認めること がある。奇形腫は一般に内部構造は不均一で soft tissue density やlow density の領域が混在し, 石灰 化も認める.

血液検査では, 悪性胚細胞性腫瘍では alpha-fetoprotein (AFP), human chorionic gonadotropin (hCG), carcinoembrynic antigen (CEA)などが腫 瘍マーカーとして有用である.HCGは絨毛癌 (choriocarcinoma), AFPは胎児性癌 (embryonal carcino$\mathrm{ma}$ ), 卵黄囊腫(yolk sac tumor)の腫瘍マーカーで 
あり，非精上皮性悪性奇形腫の 80 〜 $90 \%$ が AFP ま たは hCG 陽性である。精上皮腫でも hCG (7\%) や AFP (1％) 陽性の症例を認める. 胸腺腫は重症筋無 力症を合併することが多く, 抗アセチルコリン受容 体抗体や筋電図を測定し, 筋無力症状を検討する必 要がある11,2), 4).

これらの病歴, 症状, 画像診断や血液検査から多 くの症例で診断名を予測することができる．確定診 断には生検が必要であるが，巨大前縦隔腫瘍に関し ては，ほとんどの症例が針生検にて診断することが できる，植田らの症例もまず，局所麻酔下に針生検 を行うべきであったと考えられる，局所麻酔下生検 の手技に関しては, 前縦隔腫瘍は大血管を背側に圧 排しているため, 超音波検査では肋間からの操作で 比較的容易に腫瘤を描出することが可能で, 超音波 検査下腫瘍生検を安全に行うことができる，私たち は, 症例に従って $16 〜 22$ ゲージのツルーカット針 やシュアーカット針を使用している. 造影 CT 検査 にて腫愓と血管の走行の位置関係を確認することが 必要である。縦隔のリンパ節原発の悪性リンパ腫で 血管を胸骨の方向に圧排し, 生検が困難な場合はCT ガイド下に生検する必要がある．生検材料は小さい ため確定診断には免疫組織化学染色が有用である ${ }^{5)}$.

2. 病歴, 症状, 血液画像診断, 生検の組織学的診断か ら前縦隔腫瘍の診断がつけば, 術前治療 (化学療法 や放射線治療)を行い, 腫瘍を縮小させて全身麻酔 下根治手術を施行する

成熟型奇形腫は術前治療の効果はほとんどない. 胸腺腫および胸腺癌では化学療法と放射線治療の併 用で腫瘍を縮小させることができる場合がある．悪 性胚細胞性腫瘍では cisplatium を併用した化学療法 で，腫瘍を縮小させることができる，悪性リンパ腫 では化学療法で腫瘍を著明に縮小させることができ る ${ }^{6)}$. 術前治療を行い, 腫瘍のサイズを縮小させる ことで，全身麻酔下に根治手術を行う場合でも，全 身麻酔導入を容易にすることができる。

局所麻酔下の針生検や術前治療によって，前縦隔
巨大腫瘍に対する全身麻酔下の手術を安全に施行す ることが最も大切なことである，以下に，こうした 努力にもかかわらず，前縦隔巨大腫瘍に対する全身 麻酔を施行しなければならない症例の注意点を詳述 する。

\section{3. 術前に気道狭窄の評価を行う}

1) 体位による症状，所見(体位別の症状・所見およ び酸素飽和度を検討しておく)

患者を仰臥位，右および左側臥位，腹臥位などの 体位を取らせ, 症状 (dyspnea, noisy breathing, weakness of breath), 所見 (stridor, wheezes, rhonchi, diminished breath sounds), 酸素飽和度, 血圧および脈拍数の違いを調べておく，麻酔導入時， より良好な体位を取らせることで処置を行う時間を 稼ぐことができる。

2) spirometryにて呼吸機能を精査(肺活量 VC や 1 秒 量 FEV1.0, flow-volume曲線による胸腔内気道の 閉塞の程度，体位による違いを検討しておく）

特に flow-volume 曲線は気道閉塞を検査するのに 有用である。体位を変えて, 吸気・呼気時の両方 (固定性)で気道閉塞パターン(flattened loop) を検討 し, 気道閉塞の強い体位と少ない体位を把握するこ とは大切である7).

3）胸部 CT，3D-CTによる気道狭窄の部位と気管お よび気管支径を測定する.

気道径が $1 / 3$ 以上縮小した症例 : risk group

気道径が $1 / 2$ 以上縮小した症例： highly risk group

Azizkhan らは, 気道径が $1 / 3$ 以上縮小した症例を, 麻酔時気道狭窄を生じる risk group とし，小児の 50 例のうち麻酔時気道閉塞をきたした 5 例はすべて術 前の CT 検査で気道径が $1 / 2$ 以上縮小した highly risk groupであったと報告している ${ }^{8)}$.

4. 両足からの静脈ライン確保, 動脈ライン確保, スワ ンガンツ・カテーテルの留置

前縦隔腫瘍により上大静脈が閉塞する可能性があ るので，末梢の静脈ラインは両足より確保する．肺 
動脈を閉塞するおそれのある症例に対しては, スワ ンガンツ・カテーテルを留置しておく，大動脈は壁 が厚いので閉塞することはほとんどない.

5. 局所麻酔下に腋窝・大腿静脈一時バイパスおよび大 腿動静脈にカテーテル留置 (経皮的人工補助装置 percutaneous cardiopulmonary support (PCPS)) の

\section{準備}

前縦隔巨大腫瘍の全身麻酔導入時, 特に気管内 チューブ挿入時に体位の変化や胸腔内圧の上昇など により気道閉塞に加え, 循環障害が急激に悪化し, 致死的な SVC症候群となることがある．原因とし て, 仰臥位, 筋弛緩㓮投与による胸部筋緊張の低下, 人工呼吸による胸腔内圧の上昇などにより SCV の 圧排 $\rightarrow$ 上半身の循環血液のうつ滞に伴う静脈還流の 減少 $\rightarrow$ 重篤な循環不全, という流れが考えられる. この病態の改善に人工心肺の使用が必要であるとの 報告があるが, 下川らは腋窩・大腿静脈一時バイパ スの有用性を報告している，彼らは全身麻酔導入前 に，局所麻酔下に大腿動静脈を露出・テーピング後 に，腋窩・大腿静脈一時バイパスを作製した，圧較 差による速やかな静脈還流が可能で, 全例で内頸静 脈圧は下降し, 全身麻酔導入に際し SCV 症候群の 致死的な悪化はなかったと報告している ${ }^{9)}$. また, バイパス回路に側枝を設け，人工心肺の脱血回路の 一部として使用したとして，容易に人工心肺への移 行が可能であることを述べている ${ }^{9)}$. 植田らも述べ ているように，巨大前縦隔腫瘍の全身麻酔導入時の 呼吸不全に対して, 経皮的人工補助装置(PCPS) は 大変有用な方法であり, high risk groupに対して経 皮的人工補助装置(PCPS) を準備すべきである ${ }^{10)}$.

\section{6. 局所麻酔下に気管支鏡にて狭窄程度と狭窄部位を精查}

気道狭窄の程度と部位・距離を十分精査してお く，可能であれば，狭窄部位を超えた部位の気道の 状態も観察しておく.

\section{Awakeにて挿管し, 筋驰緩剤は使用しない}

筋弛緩剤投与による胸部筋緊張の低下による気道 およびSVCの圧迫を防ぐ.

\section{8. 術前に検討した体位を取ってみる}

右または左側臥位，腹臥位，座位など酸素分圧お よび血圧が維持できる体位をとる，仰臥位は気道お よび大血管の圧排において, 最も悪い体位である. 酸素分圧や血圧が著明に改善しなくても，より良い 体位をとることで, 以降の処置を行うための時間を 稼ぐことができる.

9. 酸素化が不十分であれば, 狭窄部位を超えてチュー

\section{ブを挿入する}

気管チューブを狭窄部位を超えて挿入することが 大切である。そのためには, 長く, 比較的径の細い 気管チューブ（内径 $6 \mathrm{~mm}$ ）を使用する。狭窄部位が 気管下部であれば，一側肺換気でもかまわない，肺 実質に障害がなければ, $100 \%$ 酸素の一側肺換気で $\mathrm{PaO}_{2}$ を $150 \mathrm{mmHg}$ 程度に維持することができる。し かし, 植田らの症例のように左主気管支の閉塞と右 肺動脈の閉塞を同時に合併する症例があるので，一 側肺換気後の酸素分圧を測定する必要がある.

\section{0. 経皮的人工補助装置 (PCPS) を行う}

今までの処置で酸素分圧および血圧を維持できな い場合は，経皮的人工補助装置(PCPS)を使用する.

11. 術後ICUに入室し, モニタリング

12. Tumor debulkingした症例は問題なく抜管できる

生検のみで終了した症例は抜管時注意が必要で ある。

\section{おわりに}

以上のような流れで，前縦隔巨大腫瘍に対する全 身麻酔下の生検および根治手術に対処していけば, ほとんどの症例で致死的な呼吸不全や循環不全を防 ぐことができると思われる。しかし, 最も大切なこ とは, 外科医, 麻酔科医が全身麻酔導入時の病態を 十分把握し, 的確な判断と迅速な行動を行うことで ある。 


\section{参考文献}

1) Shimosato $Y$, Mukai $K$ : Tumors of the mediastinum : Atlas of tumor pathology, 3rd series, AFIP, Washington, D.C., 1997

2) Marchevsky A M, Kaneko M : Surgical pathology of the mediastinum, Raven Press, New York, 1984

3) Goh MH, Liu XY, Goh YS. Anterior mediastinal masses : An anesthetic challenge. Anaesthesia $54: 670 \sim$ 682,1999

4）伊藤元彦, 藤村重文：縦隔腫瘍アトラス. 真興交易医 書出版社, 東京, 1987

5）近藤和也, 門田康正. 検査計画法：縦隔腫瘍 綜合臨 床 51 (Suppl)：1274 1278，2002

6）近藤和也, 門田康正：縦隔腫瘍に対する治療法の進歩. 呼吸 $21: 717 \sim 722,2002$
7) Vander Els NJ, Sorhage F, Bach AM, et al. : Abnoraml flow volume loops in patients with intrathoracic Hodgkin's disease. Chest $117: 1256 \sim 1261,2000$

8) Azizkhan RG, Dudgeon DL, Buck JR, et al. : Life threatening airway obstruction as a complication to the management of mediastinal masses in children. J Pediatr Surg 20:816〜822, 1985

9）下川新二, 山下拓哉, 金城玉洋ら, 胸部悪性腫場によ る上大静脈症候群の外科治療一腋䆚・大腿静脈一時バ イパスの有用性一. 日胸外会誌 $45 ： 1827 \sim 1831$, 1997

10) Tempe DK, Arya R, Dubey S, et al. : Mediastinal mass resection : Femorofemoral cardiopulmonary bypass before induction of anesthesia in the management of airway obstrucrion. J Cardiothorac Vasc Anesth 15 : 233 236, 2001 